\title{
Enhancing the production through SMED methodology
}

\author{
D. Kumaravel *, R. Sathya Bharathi, M. Kavinandini \\ Department of Mechanical Engineering, Sri Shanmugha College of Engineering and Technology \\ *Corresponding Author E-mail: kevinkumaravel@gmail.com
}

\begin{abstract}
Aim of this experiment is to improve the production rate in steering pump manufacturing industry using single minute exchange of die method. Hydraulic steering pump manufacturer often face the problem of periodically changing the machine configuration which led to frequent delays. It was observed that most machines need the fixtures to be redesigned. Thus, comes to play the concept of single minute exchange of Dies. It refers to single-digit time limit wherein every aspect of a setup change is completed in less than ten minutes. SMED is a changeover technique which is implementing to increase the output and decrease the quality losses due to changeovers. By examine the changeover process along with a stronger sense of teamwork and ownership leads to significant reduction in setup and change over times. Purpose of SMED is to find the work actually done and proper utilization of time during the changeover activity. Through the analysis, a better understanding was gained on how to do certain activities, when the line is running and also to determine the task that needs to be done to reduce the fine-tuning activities after the actual changeover. The faster the changeover time, the lesser is downtime of the machine. This project was focused on reducing the setup time based on the ideas of SMED.
\end{abstract}

Keywords: SMED, Time Study, Process flow diagram, production rate, changeover time

\section{Introduction}

Over the year there has been an increase in global competition in the manufacturing sectors, which has led to fast and frequent changes across the globe. The rapid growth of innovations has led to rampant proliferation of product. Therefore, to ensure competitiveness, companies have to seek out the best practices to meet the ever-changing demands of the customers. The key to manufacturing a wide variety of product is to have quick changeover methods, wherein it is economically feasible to manufacture small lots with little or no downtime. Change over time is a duration needed to prepare a system to change from producing the last work piece of the final batch to producing the first good piece of the new batch. Changeover times can last from a minutes to as much as weeks in the case of automobile manufacturers retooling for new models. Change over process include Clean-Up, Set-up, Start-Up. Clean-up denotes the removal of last product and material from the line. It include only the label of a package is being changed or required complete disassembly of the equipment. This may be achieved by adjusting the equipment to correspond to the next product or by changing nonadjustable change part to accommodate the product. It is usually happened by variation in the clean-up and set-up or by variability in the product or its components. The bottlenecks were caused by long tool changeover times which drove up production lot sizes. Ratio of change over time and production time gives economic lot size. One touch Exchange of Dies is far more aggressive in what it advocates. It says that with continuous improvement, die change should get to the point where they are nearly instant. From this process it is obtain that the exchange can be done with a single motion rather than multiple steps. There may not be a need to go past a certain point on the journey to OTED, because other of the system are slower.

\section{Time study}

Time study involves the real time observation of a task keeping device to record the time taken to perform a particular task. The stop watch method was used as it is a direct and a very effective method. Initially preliminary time study was performed to find how the setup is performed and the data was tabulated below.

Table 1: Initial Time Taken by the Operator

\begin{tabular}{cccccc}
\hline S.No Sequence of Activities & $\begin{array}{c}\text { SHIFT 1 } \\
\text { Operator } \\
1\end{array}$ & $\begin{array}{c}\text { SHIFT 1 } \\
\text { Operator } \\
2\end{array}$ & $\begin{array}{c}\text { SHIFT 2 } \\
\text { Operator } \\
1\end{array}$ & $\begin{array}{c}\text { SHIFT 2 } \\
\text { Operator } \\
2\end{array}$ \\
\hline 1 & Burr Cleaning & 75 & 80 & 74 & 68 \\
2 & $\begin{array}{l}\text { Clamping Stud } \\
\text { removal }\end{array}$ & 10 & 10 & 15 & 12 \\
3 & Removal 4 allen & 99 & 90 & 84 & 94 \\
& screw & & & & \\
4 & Removing top plate & 13 & 14 & 19 & 10 \\
5 & Cleaning the fixture & 156 & 142 & 148 & 153 \\
& face & & & & \\
6 & Cleaning the top plate & 85 & 67 & 79 & 72 \\
7 & Mounting the plate & 25 & 30 & 24 & 28 \\
8 & Fixing the screw(4) & 156 & 148 & 140 & 152 \\
9 & Fixing clamping stud & 28 & 28 & 24 & 32 \\
10 & Giving air hose & 135 & 117 & 121 & 128 \\
& connections & & & & \\
Total & In sec & 782 & 726 & 728 & 749 \\
In min & 13.03 & 12.1 & 12.13 & 12.48 \\
\hline
\end{tabular}


It was observed that most machines need the top plate of their fixtures to redesign. Therefore, a separate time study of the same has beenperformed. The readings were taken for 4 operators over two different shifts. This gives us a normal population and therefore a smaller magnitude of the standard deviation and variance.

Table 2: Operation on each Machine

\begin{tabular}{|c|c|c|c|c|}
\hline S. No & $\begin{array}{l}\text { Machine } \\
\text { Name }\end{array}$ & Operations & $\begin{array}{l}\text { Changes made in } \\
\text { Fixture }\end{array}$ & $\begin{array}{l}\text { Time } \\
\text { Taken } \\
\text { (min) }\end{array}$ \\
\hline \multirow[t]{2}{*}{1} & \multirow{2}{*}{ Machine 1} & $\begin{array}{l}\text { Pump mounting } \\
\text { hole }\end{array}$ & $\begin{array}{l}\text { Butting pin for } \\
\text { orientation }\end{array}$ & 6 \\
\hline & & Cartridge hole & $\begin{array}{l}\text { Butting pin and } \\
\text { clamping stub }\end{array}$ & 17 \\
\hline \multirow[t]{2}{*}{2} & Machine 2 & Suction port hole & $\begin{array}{l}\text { Top plate has to } \\
\text { be changed }\end{array}$ & 13 \\
\hline & & By pass hole & $\begin{array}{l}\text { Top plate has to } \\
\text { be changed }\end{array}$ & 13 \\
\hline \multirow[t]{2}{*}{3} & Machine 3 & Lube hole & $\begin{array}{l}\text { Complete fixture } \\
\text { has to be changed }\end{array}$ & 17 \\
\hline & & Pressure port hole & $\begin{array}{l}\text { Top plate has to } \\
\text { be changed }\end{array}$ & 13 \\
\hline \multirow[t]{2}{*}{4} & Machine 4 & Orifice hole & $\begin{array}{l}\text { Top plate has to } \\
\text { be changed }\end{array}$ & 13 \\
\hline & & $\begin{array}{l}\text { Name plate } \\
\text { milling }\end{array}$ & $\begin{array}{l}\text { Top plate has to } \\
\text { changed }\end{array}$ & 13 \\
\hline \multirow[t]{2}{*}{5} & Machine 5 & $\mathrm{CV}$ bore & $\begin{array}{l}\text { Top plate has to } \\
\text { be changed }\end{array}$ & 13 \\
\hline & & & TOTAL & 118 \\
\hline
\end{tabular}

\section{Process flow diagram}

The process flow diagram visually represents the flow of data, raw material in our case through the various machining centers, the operations and the sequence in which they are performed. A process flow diagram is essentially a graphical representation of how a task is performed. Outline process chart is used in this experiment which gives a bird's eye view of the whole process. It is a graphical representation of the points at which the materials are introduced into a process and the sequence of all operations and inspections associated with it. The process flow diagram helps us to uncover the steps that are redundant or misplaced. In addition, process flow diagrams are used to identify appropriate team members, wherein every person is allocated the job he is best at. It also allows us to identify areas for improvement or increased efficiency, and to generate hypotheses about causes. The process flow diagram for the fixture changeover is given below by using this chart other unwanted activities can be eliminated. Internal activities refers to the task that can be done only when the machine is stopped. External activities are those that can be done even when the machine is running. Thus the best way to reduce the setup time is to convert as much of the setup time into external. Internal activities that can be converted into external by preheating die molds rather than header after setup, performing centering operation on a standardized jig before fitting tool to machine, using a tool trolley, using one operator to unscrew and another to fit the new fixture, debarring and cleaning the fixture beforehand, filtering the coolant simultaneously and use a single size screw for all clamping.

\section{Reduction of setup time}

Eliminate-Combine-Rearrange-Simplify System (ECRS) is used to reduce set time by eliminating all the unnecessary activities and the activities that cannot be eliminated are optimized in the best possible way.
Table 3: Flow Process Chart

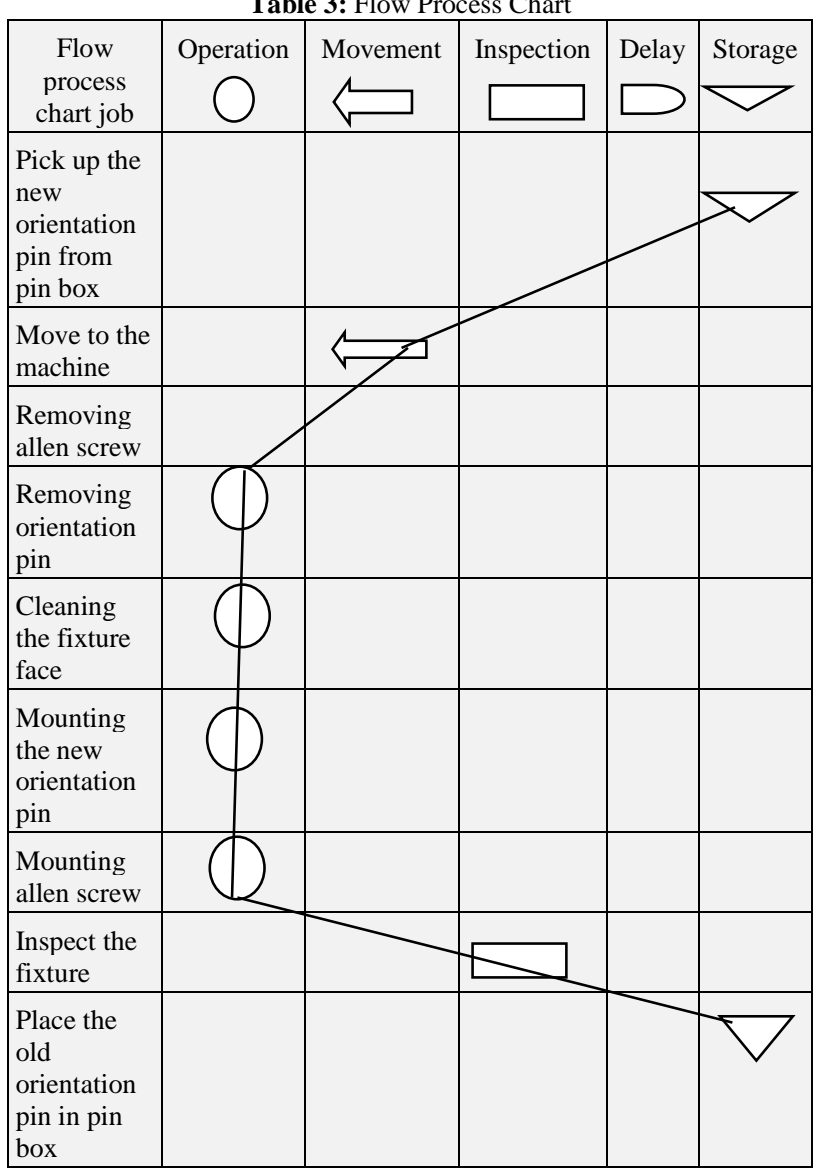

Table 4: ECRS Chart

\begin{tabular}{|c|c|c|c|c|c|c|}
\hline S.No & Sequence of Activities & Time Consumed & $\mathrm{E}$ & $\mathrm{C}$ & $\mathrm{R}$ & $\mathrm{S}$ \\
\hline 1 & Burr Cleaning & 75 & & - & - & - \\
\hline 2 & Clamping stud removal & 10 & - & - & - & - \\
\hline 3 & Remove 4 allen screw & 99 & - & - & $\checkmark$ & - \\
\hline 4 & Removing orientation pin & 0 & - & - & - & - \\
\hline 5 & Removing top plate & 13 & $\checkmark$ & - & - & - \\
\hline 6 & Cleaning the fixture & 156 & - & - & - & - \\
\hline 7 & Cleaning the top plate & 85 & - & - & - & $\checkmark$ \\
\hline 8 & Mounting the plate & 25 & $\checkmark$ & - & - & - \\
\hline 9 & Mounting orientation pin & 0 & - & - & - & - \\
\hline 10 & Fixing the screw(4) & 156 & - & - & $\checkmark$ & - \\
\hline 11 & Fixing clamping stud & 28 & - & - & - & $\checkmark$ \\
\hline 12 & Giving air hose connections & 135 & $\checkmark$ & - & - & - \\
\hline Total & In sec & 782 & & & & \\
\hline Time & In $\min$ & 13.03 & & & & \\
\hline
\end{tabular}

\section{Experimentation}

To reduce the change over time, a constant or a universal fixture has to be designed. So, the fixture has to provide space for all the models. Firstly, the various dimensions of all the models of pump is recorded and a common dimension has to be found. The table below shows all the vital parameters and the common dimensions of the pump variants. 


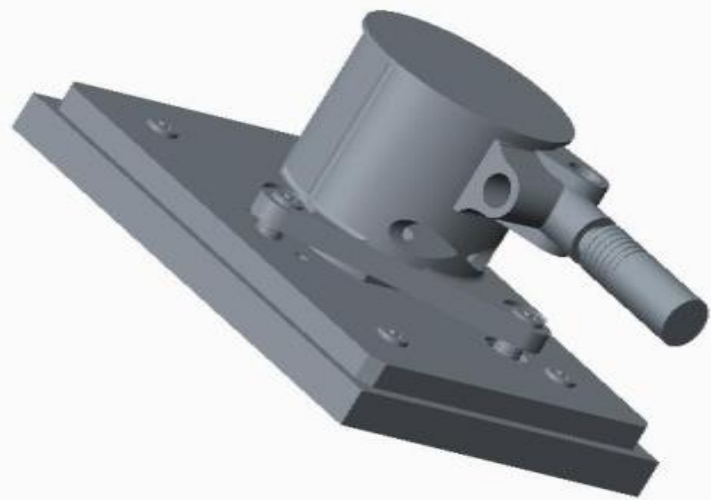

Fig.1: Resigned Fixture

Table 5: Vital Parameters for the Pump Variants

\begin{tabular}{cccc}
\hline S.No & Model name & $\begin{array}{c}\text { Spigot diameter } \\
(\mathrm{mm})\end{array}$ & $\begin{array}{c}\text { Orientation pin } \\
\text { diameter }(\mathrm{mm})\end{array}$ \\
\hline 1 & $\mathrm{~A}$ & $51.97-51.99$ & $10.95-10.96$ \\
2 & $\mathrm{~B}$ & $57.09-57.12$ & $10.95-10.96$ \\
3 & $\mathrm{C}$ & $57.09-57.12$ & $11.05-11.06$ \\
4 & $\mathrm{D}$ & $63.45-63.48$ & $8.43-8.45$ \\
5 & $\mathrm{E}$ & $82.49-82.47$ & $11.05-11.06$ \\
\hline
\end{tabular}

It is found that the diameter $26 \mathrm{~mm}$ is constant for all the variants. So this diameter can be used as the location point. Thus the common location point and common orientation point is found out for all the variants.

\section{Result}

From the table it is found that time taken for changing from a model in a single machine is reduced from 13.03 minutes to 5.1 minutes. Thus single digit time obtained for changeover in a single machine. When it comes to whole layout reduction increases in huge factor.

Table 6: Final Proposed Time (Single Machine)

\begin{tabular}{clcc}
\hline S.No & Sequence of Activities & $\begin{array}{c}\text { Time Consumed } \\
(\mathrm{sec})\end{array}$ & $\begin{array}{c}\text { Proposed Time } \\
(\mathrm{sec})\end{array}$ \\
\hline 1 & Burr Cleaning & 75 & 0 \\
2 & Clamping stud removal & 10 & 10 \\
3 & Remove 4 allen screw & 99 & 24 \\
4 & Removing orientation & 0 & 20 \\
& pin & 13 & 0 \\
5 & Removing top plate & 156 & 125 \\
6 & Cleaning the fixture & 85 & 30 \\
7 & Cleaning the top plate & 25 & 0 \\
8 & Mounting the plate & 0 & 35 \\
9 & Mounting orientation & & 39 \\
& pin & 156 & 25 \\
10 & Fixing the screw(4) & 28 & 0 \\
11 & Fixing clamping stud & 135 & 308 \\
12 & Giving air hose & 782 & 5.1 \\
Total & connections & 13.03 & \\
Time & In min & & \\
\hline
\end{tabular}

Thus the time taken for a model changeover is reduced from 118 minutes to 70.6 minutes. Thus there will be a gain in the manufacturing time of the pump and so the productivity increases.
Table 7: Total Changeover Time

\begin{tabular}{|c|c|c|c|c|c|}
\hline $\begin{array}{l}\text { S. } \\
\text { No }\end{array}$ & $\begin{array}{l}\text { Machine } \\
\text { Name }\end{array}$ & Operations & $\begin{array}{l}\text { Changes made } \\
\text { in Fixture }\end{array}$ & $\begin{array}{l}\text { Time } \\
\text { Taken } \\
(\min ) \\
\end{array}$ & $\begin{array}{c}\text { Proposed } \\
\text { Time Taken } \\
(\mathrm{min})\end{array}$ \\
\hline \multirow[t]{2}{*}{1} & $\begin{array}{l}\text { Machine } \\
1\end{array}$ & $\begin{array}{l}\text { Pump } \\
\text { mounting } \\
\text { hole }\end{array}$ & $\begin{array}{l}\text { Butting pin for } \\
\text { orientation }\end{array}$ & 6 & 6 \\
\hline & & $\begin{array}{l}\text { Cartridge } \\
\text { hole }\end{array}$ & $\begin{array}{l}\text { Butting pin and } \\
\text { clamping stub }\end{array}$ & 17 & 17 \\
\hline 2 & $\begin{array}{l}\text { Machine } \\
2\end{array}$ & $\begin{array}{l}\text { Suction port } \\
\text { hole }\end{array}$ & $\begin{array}{l}\text { Top plate has to } \\
\text { be changed }\end{array}$ & 13 & 5.1 \\
\hline \multirow[t]{3}{*}{3} & $\begin{array}{l}\text { Machine } \\
3\end{array}$ & By pass hole & $\begin{array}{l}\text { Top plate has to } \\
\text { be changed }\end{array}$ & 13 & 5.1 \\
\hline & & Lube hole & $\begin{array}{l}\text { Complete fixture } \\
\text { has to be } \\
\text { changed }\end{array}$ & 17 & 17 \\
\hline & & $\begin{array}{l}\text { Pressure port } \\
\text { hole }\end{array}$ & $\begin{array}{l}\text { Top plate has to } \\
\text { be changed }\end{array}$ & 13 & 5.1 \\
\hline \multirow[t]{2}{*}{4} & $\begin{array}{l}\text { Machine } \\
4\end{array}$ & Orifice hole & $\begin{array}{l}\text { Top plate has to } \\
\text { be changed }\end{array}$ & 13 & 5.1 \\
\hline & & $\begin{array}{l}\text { Name plate } \\
\text { milling }\end{array}$ & $\begin{array}{l}\text { Top plate has to } \\
\text { changed }\end{array}$ & 13 & 5.1 \\
\hline \multirow[t]{2}{*}{5} & $\begin{array}{l}\text { Machine } \\
5\end{array}$ & $\mathrm{CV}$ bore & $\begin{array}{l}\text { Top plate has to } \\
\text { be changed }\end{array}$ & 13 & 5.1 \\
\hline & & & TOTAL & 118 & 70.6 \\
\hline
\end{tabular}

\section{Conclusion}

In this project, setup time for steering pump manufacturing was reduced properly to increase the production rate. Time study was done in order to find the time taken for each operation.EliminateCombine-Rearrange-Simplify System (ECRS) was implemented to reduce the unnecessary activities in a possible way.New fixture was designed by consider common location point and common orientation point. It is found that after implementing new method the production time was reduced from 782 seconds to 308 seconds.

\section{Acknowledgement}

This experiment was supported by Sri Shanmugha College of Engineering and Technology. We thank our colleagues who provided insight and expertise that greatly assisted the experiment, although they may not agree with all of the interpretations of this paper.

\section{References}

[1] Amir Azizi, "Designing a Future Value Stream Mapping to Reduce Lead Time Using SMED-A Case Study", Procedia Manufacturing, Volume 2, Pages 153-158, 2015

[2] Andreia Simões, Alexandra Tenera, "Improving setup time in a Press Line - Application of the SMED methodology", IFAC Proceedings Volumes, Volume 43, Pages 297-302, 2010

[3] Brito.M, Ramos.A.L, "Combining SMED methodology and ergonomics for reduction of setup in a turning production area", Procedia Manufacturing, Volume 13, Pages 1112-1119, 2017

[4] Cecil.J, "Computer aided fixture design: Using information intensive function models in the development of automated fixture design systems", Journal of Manufacturing Systems, Volume 21, Pages 58-71, 2002

[5] Chee-Cheng Chen, "An objective-oriented and product-linebased manufacturing performance measurement, International Journal of Production Economics", Volume 112, Pages 380-390, 2008

[6] Eyler R.Coates, Bhaba R.Sarker, Manufacturing setup cost reduction, Computers \& Industrial Engineering, Volume 31, Pages 111-114, 1996 
[7] Gunay.E.E, Kula.U, "Integration of production quantity and control chart design in automotive manufacturing", Computers \& Industrial Engineering, Volume 102, Pages 374-382, 2016

[8] Hans-ChristianMöhring, "Intelligent Fixtures for High Performance Machining, Procedia CIRP”, Volume 46, Pages 383-390, 2016

[9] Helio Yochihiro Fuchigami, "A survey of case studies in production scheduling: Analysis and perspectives", Journal of Computational Science, 2017

[10] Hui Wang, "Computer aided fixture design: Recent research and trends, Computer-Aided Design", Volume 42, Pages 1085-1094, 2010

[11] Iain Boyle, "A review and analysis of current computer-aided fixture design approaches", Robotics and Computer-Integrated Manufacturing, Volume 27, Pages 1-12, 2011

[12] Jiaqin Yang, Richard H.Deane, "Setup time reduction and competitive advantage in a closed manufacturing cell", European Journal of Operational Research, Volume 69, Pages 413-423, 1993

[13] Jian-BoYu, ShijinWang, "Using Minimum Quantization Error chart for the monitoring of process states in multivariate manufacturing processes", Computers \& Industrial Engineering, Volume 57, Pages 1300-1312, 2009

[14] Kemal Karasu.M, Mehmet Cakmakci, "Improvement of changeover times via Taguchi empowered SMED/case study on injection molding production, Measurement", Volume 47, Pages 741-748, 2014

[15] Liu.A.C, Wong.K.S, "Automatic generation of process flow diagrams, Computers \& Graphics", Volume 12, Pages 525-539, 28-141, 2001

[16] Mashitah Mohamed Esa, Nor Azian Abdul Rahman, "Reducing High Setup Time in Assembly Line: A Case Study of Automotive Manufacturing Company in Malaysia", Procedia Social and Behavioral Sciences, Volume 211, Pages 215-220, 2015

[17] Mateusz Kikolski, "Study of Production Scenarios with the Use of Simulation Models", Procedia Engineering, Volume 182 , Pages 321-328, 2017

[18] Metin Dağdeviren, Ergün Eraslan, “An alternative work measurement method and its application to a manufacturing industry", Journal of Loss Prevention in the Process Industries, Volume 24, Pages 563-567, 2011

[19] Meurig Thomas, "Normalised model-based processing diagrams for additive layer manufacture of engineering alloys", Acta Materialia, Volume 108, Pages 26-35, 2016

[20] Mohammed Ali Almomani, Mohammed Aladeemy, "A proposed approach for setup time reduction through integrating conventional SMED method with multiple criteria decisionmaking techniques", Computers \& Industrial Engineering, Volume 66, Pages 461-469, 2013

[21] Moustapha Diaby, "Optimal setup time reduction for a single product with dynamic demands", European Journal of Operational Research,

[22] NoriahYusoff, AhmedJaffar, Work Measurement for Process Improvement in the Car Seat Polyurethane Injection Manufacturing Line, Procedia Engineering, Volume 41, Pages 1800-1805, 2012

[23] Pablo Guzmán Ferradás, Konstantinos Salonitis, "Improving Changeover Time: A Tailored SMED Approach for Welding Cells", Procedia CIRP, Volume 7, Pages 598-603, 2013

[24] Papastathis.T, Bakker.O, "Design Methodology for Mechatronic Active Fixtures with Movable Clamps", Procedia CIRP, Volume 3, Pages 323-328, 2012

[25] Poonam Magu, Kumud Khanna, "Path Process Chart - A Technique for Conducting Time and Motion Study", Procedia Manufacturing, Volume 3, Pages 6475-6482, 2015

[26] Rodolfo Rodríguez-Méndez, "Diana Sánchez-Partida, A case study: SMED \& JIT methodologies to develop continuous flow of stamped parts into AC disconnect assembly line in Schneider Electric Tlaxcala Plant", IFAC-Papers On Line, Volume 48, Pages 1399-1404, 2015

[27] Rosa.C, Silva.F.J.G, "SMED methodology: The reduction of setup times for Steel Wire-Rope assembly lines in the automotive industry”, Procedia Manufacturing, Volume 13, 2017

[28] Roy A. Parisher, Robert A. Rhea, "Flow Diagrams and Instrumentation", Pipe Drafting and Design, Pages 134-153, 2012
[29] Russell A.Matthews, Janet L.Barnes-Farrell, "Advancing measurement of work and family domain boundary characteristics", Journal of Vocational Behavior, Volume 77, Pages 447-460, 2010

[30] SenthilKumar.A, "Expert fixture-design system for an automated manufacturing environment", Computer-Aided Design, Volume 24, Pages 316-326,

[31] Stefan Seifermann, Jörg Böllhoff, "Evaluation of Work Measurement Concepts for a Cellular Manufacturing Reference Line to Enable Low Cost Automation for Lean Machining", Procedia CIRP, Volume 17, Pages 588-593, 2014

[32] Voinov.A.A, "Conceptual Diagrams and Flow Diagrams", Encyclopedia of Ecology, Pages 731-737, 2008

[33] Yiming Rong, Tsuchin Chu, "Fixturing Feature Recognition for Computer-aided Fixture Design", IFAC Proceedings Volumes, Volume 25, Pages 97-100, 1992

[34] Yuchun $\mathrm{Xu}, \mathrm{Mu}$ Chen, "Improving Just-in-Time Manufacturing Operations by Using Internet of Things Based Solutions", Procedia CIRP, Volume 56, Pages 326-331, 2016

[35] S.V.Manikanthan and T.Padmapriya "Recent Trends In M2m Communications In 4g Networks And Evolution Towards 5g", International Journal of Pure and Applied Mathematics, ISSN NO:1314-3395, Vol-115, Issue -8, Sep 2017.

[36] T. Padmapriya and V.Saminadan, "Improving Performance of Downlink LTE-Advanced Networks Using Advanced Networks Using Advanced feedback Mechanisms and SINR Model", International Conference on Emerging Technology (ICET), vol.7, no.1, pp: 93, March 2014 